\title{
On the Relationship Between Teacher Autonomy and Learner Autonomy
}

\author{
Ligang $\operatorname{Han}^{1}$ \\ ${ }^{1}$ English Department, North China Electric Power University, Baoding, Hebei, China \\ Correspondence: Ligang Han, English Department, North China Electric Power University, Baoding City, Hebei \\ Province, China.
}

Received: March 20, 2020

Accepted: April 25, $2020 \quad$ Online Published: May 29, 2020

doi:10.5539/ies.v13n6p153

URL: https://doi.org/10.5539/ies.v13n6p153

\begin{abstract}
With the research on fostering and cultivating learner autonomy in foreign/second language teaching and learning, teacher autonomy has gained momentum in the research of foreign language teacher education. There have been many theoretical research and discussions about the definitions of learner autonomy. Many researchers acknowledge that language teachers play important roles in developing learner autonomy. However, the relationship between teacher autonomy and learner autonomy needs to be explored. The focal point of the present paper is a tentative discussion on the relationship between teacher autonomy and learner autonomy in foreign language education and teacher education. This paper sheds light to foreign language education and teacher education in that language teachers should change their traditional roles to ones catering and facilitating the development of learner autonomy, and teacher education and training programs should include and design courses, practicum to enhance and promote teacher-learner autonomy.
\end{abstract}

Keywords: teacher autonomy, learner autonomy, teacher's role, foreign language education

\section{Introduction}

In the traditional foreign language teaching, foreign language teachers are the centre and dominant of the teaching and learning process. Language learners passively acquire knowledge that is imparted by language teachers. As a result, language learners depend much on the teachers and lack of autonomy and agency in learning. In recent years, the research focus has been shifted from "teacher-centeredness" to "learner-centeredness". More current foreign language teaching approaches even advocate "learning-centered" paradigm (Hutchinson \& Waters, 1987).

In Western countries, some educators propose that one of the most important goals in education is to develop learner autonomy (e.g. Broady \& Kenning, 1996; Benson, 1997; Benson, 2004; Allford \& Pachler, 2007; Jiménez-Raya \& Lamb, 2008; Jiménez-Raya \& Vieria, 2015).

It is also true in China. In 2007, the Higher Education Department of Chinese Ministry of Education issued and published the reformed College English Curriculum Requirements, which provides guidelines and tenets for College English teaching to non-English major students. According to the reformed College English Curriculum Requirements, one of the teaching objectives of College English is to enhance and promote students' ability to study independently (Higher Education Department of the Ministry of Education, 2007).

As a matter of fact, developing and fostering learner autonomy has not only become a tertiary educational goal in modern foreign languages education, but also a lifelong goal for learners of all ages. Just as a Chinese saying goes, "If you give a man a fish, you feed him for a day; if you teach a man to fish you feed him for a lifetime". This educational philosophy is often quoted and referenced to emphasize the significance of "autonomous learning" (Hedge, 2002).

Originated from the research and concern on learner autonomy, the term "teacher autonomy" was introduced into the field of foreign language education (Benson, 2006; Smith, 2003). Little (1995) published a journal article-Learning as dialogue: The dependence of learner autonomy on teacher autonomy, which marked the beginning of "teacher autonomy" in second (foreign) language education research.

After years of research, researchers and scholars still have different understandings about what "learner autonomy" and "teacher autonomy" connotate. Therefore, it is of vital importance to define the two terms before a detailed discussion about their relationship. 
In the present paper, based on explicating the different definitions put forward by researchers from different perspectives, the focus is upon a theoretical exploration how teacher education facilitates language teacher-learner autonomy, which influences the teaching practice of cultivating and developing learner autonomy.

\section{Research on Learner Autonomy in Language Teaching and Learning}

The concept of autonomy first entered into the field of language teaching and learning through the Council of Europe's Modern Languages Project, which was established in 1971 (Benson, 2011). One of the achievements of the project was the founding of the Centre de Recherches et d'Applications en Langues (CRAPEL) at the University of Nancy, France (Holec, 1981), which soon became a focal point for research and practice in the field. Holec's (1981) project report to the Council of Europe is a primary early document on autonomy in language learning and teaching.

There are several terms relating to learner autonomy but have different connotations. Many researchers (e.g. Benson, 2005, 2011) now agree that "learner autonomy" and "autonomous learning" mean differently from "self-instruction", "self-directed learning", "individualized learning", "independent learning", "self-access", "distance learning" or "out-of-class learning". Therefore, it is necessary to define the connotations of learner autonomy before discussing the influencing factors.

\subsection{Definitions of Learner Autonomy}

As to the definition of learner autonomy, it may be the single yet most difficult question to address and any answer to it is likely to be subjective. Benson (2006) emphasized the importance to define learner autonomy in language learning as follows, if educators and language teachers are to cultivate and foster autonomy, they need to know and be clear about what it is that they are trying to foster or develop.

The definitions of learner autonomy have been evolving and changing with times. Holec (1981, p. 3) defined autonomy as "the ability to take charge of one's own learning". This widely cited definition has worked well as the framework for language teaching and learning research and practice. To Holec (1981), "taking charge of one's own language learning" involves determining learning objectives, learning content, and learning progression, selecting learning methods and techniques, monitoring acquisition, and evaluating learning outcomes.

Accordingly, the role(s) of the language teacher for autonomous learners is to facilitate and help them to assume the responsibility for making relevant decisions concerning their learning in the following aspects: 1) determining the learning objectives; 2) defining the learning contents and progressions; 3) selecting learning methods and techniques to be used; 4) monitoring the procedure of acquisition;5) evaluating what has been acquired.

It is important to note that Little (1990) provided a very useful clarification about what autonomy is not. Little (1990) argues that autonomy is: 1) not a synonym with self-instruction; 2) not a matter of letting learners get on with things as best they can, 3) not a teaching method, 4) not a single easily described behavior, 5) and not a steady and stable state. What can be drawn from this is that autonomy involves the attributes of the language learner, and autonomy is likely to be varied from different learners and contexts.

Based on reviewing the literature on the definitions of "learner autonomy", Han (2013) put forward an "learner autonomy dynamics model". As is illustrated in Figure 1, learner autonomy has three distinct traits.

First of all, learner autonomy involves "learner's attitude and motivation". In other words, Language learner likes to take an active attitude and integrative motivation towards his/her study, and takes the initiative to be responsible for his/her own study.

Second, the development of learner autonomy needs a "supportive context" or environment. The learning context includes language teacher's guidance, learning facilities (e.g. self-access centers, learning softwares, smart phone English learning applications), and learning materials and resources (electronic and hard copies).

Most important of all, learner autonomy is considered as learner's “capacity/ability of learning". Through learner training and teacher support, language learner can learn how to learn and develop the capacity/ability, acquire learning methods and strategies to learn independently. 


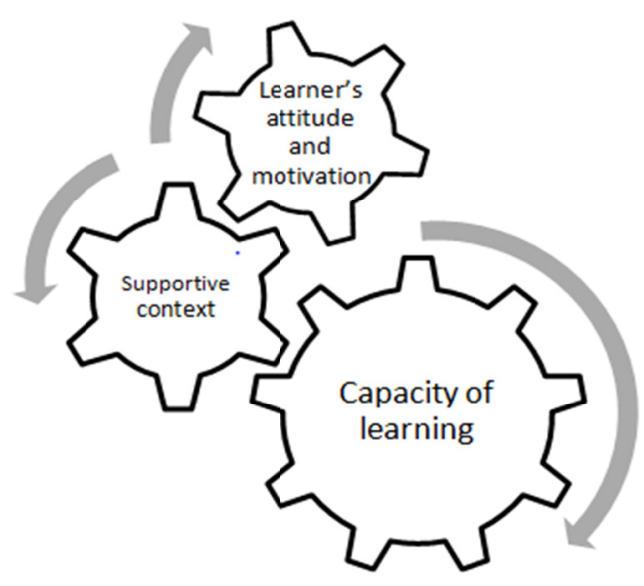

Figure 1. The learner autonomy dynamics model

The three parts work together and form the developing dynamics of learner autonomy. This definition is insightful in the following aspects. First of all, language learner needs to make his agency of learning to full play. That is to say, language learner needs to reflect on his/her met-cognition, cognition and motivation about learning, which gives the learner a clear picture and understanding that he/she is obliged to take charge of his/her own learning and be responsible for it.

Next, the degree of learner autonomy is like developing on a continuum. In other words, the degree of autonomy may vary from person to person, and from different stages of learning. Language learner autonomy development is a constructive and developing process, which leaves space for cultivation and promotion.

Finally, there are various intricate, complex factors that influence the development of learner autonomy.

\subsection{Factors Influencing the Development and Fostering of Learner Autonomy}

The research on the factors that influence the fostering of learner autonomy is also the focus of many researchers and educators.

Some scholars analyze the influencing factors from the internal and external perspectives. For example, Pang (2003) analyzed the internal and external factors that influence the development and fostering of learner autonomy. Pang (2003) points out the internal factors include learner's self efficacy, attribute, acquisition of cognitive strategies, the development level of meta-cognition, degree of self-discipline and gender roles. The external factors include school educational context (teaching mode, teaching materials and organization, educational technology, classroom management), family and cultural factors.

Similarly, Xu (2007) analyzed the influencing factors from the psychological and social perspectives. According to $\mathrm{Xu}$ (2007), the internal factors include learner's self-efficacy, attribute, learning motives, learning attitude, learning styles and learning strategies. The external factors include foreign language teachers, educational technology, peer learning groups, learning environments and social culture.

There are also other research perspectives. Aoki (2000) explored how affect factors influence the development and fostering of learner autonomy. Aoki $(2000,2002)$ argues that language teachers can facilitate and promote the development of learner autonomy by having confidence in the language learner, creating a conducive psycho-secure learning environment, allowing the learner to make choice (about learning), giving leaner the space of negotiation, allowing (learner) to express opinions freely, providing learning information, justifying the choice that the learner has made (about learning), encouraging and supporting learner to reflect on the cognition, affect and social factors that involve in the learning process.

Dickinson (1992) introduced the techniques and skills of learner training, and argued the importance of improving learner's language awareness and language learning awareness. If language learner can have an overall, clear understanding and knowledge of language and language learning, he or she will benefit greatly in language learning.

Wenden (1991) explored learning strategies, learner attitude and learner belief from theoretical and empirical studies. Ushioda (1996) analyzed the relationship between motivation and learner autonomy. Littlewood (1999) 
did research on how cultural factors influence the development of learner autonomy.

In short, researchers and scholars agree on that the influencing factors are like intertwining matrix that determine the development mechanism of learner autonomy. No matter what perspective that researchers take to analyze the influencing factors, language teachers, to a large extent, play crucial roles in the development and fostering of learner autonomy.

\section{Research on Teacher Autonomy in Language Teaching and Learning}

The idea of teacher autonomy arises partly from a shift in the field of teacher education from a focus on the teacher as a conduit for methods devised by experts to a focus on the teacher as a self-directed learner and practitioner (Benson, 2011). It was Little's (1995) paper that first brought the term into language education. What Little (1995) contributes is the insightful application from practice in classrooms to the theoretical construct and exploration of teacher autonomy.

Just as the difficulty in defining learner autonomy, it is also not easy to define teacher autonomy. Xu (2007) explains why it is very difficult to define the concept of teacher autonomy. It is because language teacher has multi-roles to play in language teaching and learning. In the first place, language teacher plays the role as an instructor to the learners. In the second place, language teacher is also a teacher researcher and a learner as well.

Different researchers emphasize different aspects of teacher autonomy, thus have different definitions. To Little (1995, p. 179), teacher autonomy is teacher's "capacity for autonomous learning", which is shown in teacher's "personal responsibility", "continuous reflection", "analysis of degree of affective and cognitive control" and "exploiting freedom" in the teaching process.

Similarly, McGrath (2000) defines teacher autonomy as "self-directed professional development and freedom (from control by others)". McGrath (2000) emphasizes teacher's "control" on the professional development. Likewise, Smith (2003, p. 4) defines teacher autonomy as "professional action and professional development". Smith (2003) further explains the dimensions relating to "professional action" and "professional development".

Thavenius (1999) explained teacher autonomy in relation to learner autonomy. According to Thavenius (1999, p. 160 ), teacher autonomy refers to language teacher's "ability" and "willingness" to help students take responsibility for their own learning. Thavenius (1999) points out that an autonomous teacher will reflect on his/her role and make changes to help learners become independent and autonomous.

Taking the stages of teacher development into consideration, Vieira $(2008$, p. 200) defines teacher autonomy into two parts: "teacher-as-learner autonomy" and "teacher-as-teacher autonomy". This definition sheds light on teacher education programs. The research on teacher autonomy should consider the different phases of teacher development.

Huang \& Benson (2007, p. 35) define teacher autonomy as "professional attribute". It involves the "capacity of control" over the second/foreign language teaching process, and "capacity for self-directed professional development".

From the review of relevant literature, Han $(2013,2017)$ puts forward a comprehensive definition for language teacher autonomy. According to Han $(2013,2017)$, language teacher autonomy can be defined as "the professional attribute" of language teacher, which involves two aspects: language teacher's "professional freedom", language teacher's "ability/capacity and willingness to take action for self-directed professional development". In other words, Teacher autonomy is embodied and exercised in language teachers flexibility to cope with both external and internal constraints for the benefits of (second/foreign) language learning, professional ambitions and motives to exert his/her full potential and capacity for self-directed professional development, and realization to develop learner autonomy to achieve lifelong learning.

\section{The Relationship Between Teacher Autonomy and Learner Autonomy}

It is asserted by some researchers and scholars (e.g. Aoki, 2002; Breen \& Mann, 1997; Little, 1995) that teacher autonomy and learner autonomy are dependent on each other. Just as Aoki (2002) compared the relationship between learner autonomy and teacher autonomy to the two sides of one coin.

\subsection{Theoretical Exploration and Model Constructs}

Though learner autonomy and teacher autonomy are closely related to each other, how to bridge the gap between them? This can be in part achieved through foreign language teacher education. Then there comes another question: how can foreign language teacher education programs promote the pedagogy and practice for developing autonomy in schools and universities? These are two intriguing questions that are worth taking into consideration in teacher education programs. 
Language teachers expect teacher education programs to help them broaden and increase their practical knowledge and teaching skills, contribute and promote their professional development, and enhance their effectiveness with language learners. Moreover, they hope to gain specific, concrete and practical ideas that directly relate to the everyday operations of their classrooms (Jiménez-Raya, 2008). Therefore, the language teacher development programs that fail to address these needs are unlikely to succeed. Foreign language teacher education programs must also empower teachers to become protagonists in their professional lives. In this sense, language teacher self-development becomes the ultimate goal of teacher education (Jiménez-Raya, 2008).

Linking the phases of teacher development, Vieira (2008, p. 199) puts forward an insightful "autonomy triangle" "teacher-as-learner autonomy", "teacher-as-teacher autonomy", and "learner autonomy" (see Figure 2). This model is conducive to help teacher educators understand the interrelationships between teacher autonomy and learner autonomy. Vieira (2008) further explains that in the figure, the terms "teaching" and "learning" are broad in scope, which means that the expression "learning how to learn" under "learner autonomy" is meant to include all that students as "learners of learning" might learn so as to develop their autonomy (and not only learning strategies).



Figure 2. The autonomy triangle (Vieira, 2008, p. 200)

Likewise, to clarify the claim that the fostering of learner autonomy is dependent on teacher autonomy, Little (2000) argued that it is not reasonable to expect language teachers to foster and cultivate learner autonomy if they themselves do not know what it is to be an autonomous learner. Consequently, teacher autonomy can be developed through educational interventions, teacher education and teacher training programs parallel to those leading to the development and fostering of learner autonomy (Benson, 2011). Therefore, language teacher education and training programs should not only teach student teachers about learner autonomy, how to foster learner autonomy, but more importantly, should have teacher autonomy as an orientation goal.

In addition to expand teacher education programs to include the orientation goal of developing teacher autonomy and learner autonomy, more theoretical discussion and empirical research need to be carried out to explore the relationship between the two. McGrath (2000) proposed that teacher research, action research, reflective practitioner are a number of the strands that go together with teacher autonomy. So language teachers can design and research on the relationship between teacher autonomy and learner autonomy through action research in their respective educational contexts.

Inspired by Vieira's (2008) "autonomy triangle", Han (2013) proposed a theoretical model (see Figure 3) to explore the relationship between teacher autonomy and learner autonomy.

As is illustrated in Figure 3, first, student teacher's autonomy development experience will influence his/her belief and practice in fostering learner autonomy (LA). Second, language teacher's pedagogical knowledge acquired through pre-service and in-service teacher education and training programs will also influence his/her belief and teaching practice. Third, student teacher's autonomy experience, belief and practice of the development of learner autonomy, teacher's pedagogical knowledge acquired through pre-service and in-service teacher education programs, all of the three intertwine and work together to influence the teacher's roles in fostering learner autonomy, which further determines the effectiveness in developing learner autonomy.

Based on the framework, Han (2013) carried out a mixed methods research combing case study and survey 
research, and analyzed language teacher's pedagogical knowledge for the development and promotion of learner autonomy.

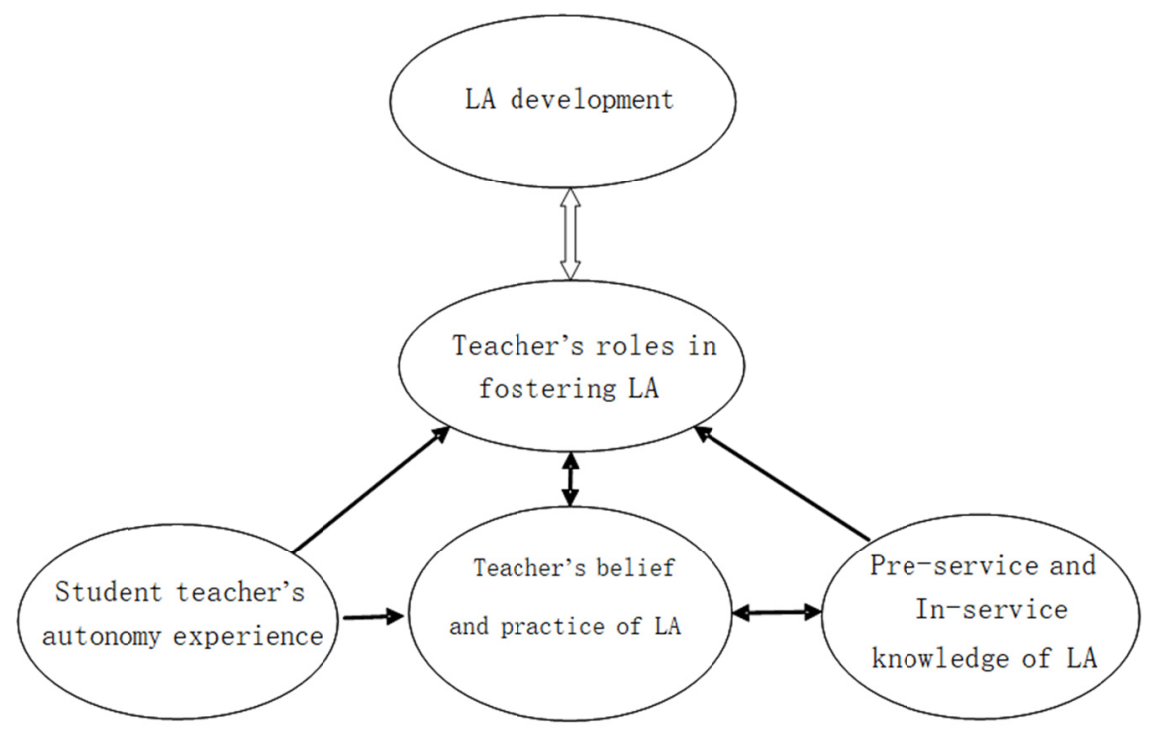

Figure 3. Teacher autonomy-learner autonomy developmemnt model

\subsection{Relevant Empirical Research}

Compared with the theoretical discussion and exploration, there has been little empirical evidence and research that will undermine the theoretical assumptions.

Smith $(2003,2010)$ was among the first researchers who paid attention to develop "teacher-learner autonomy". $\operatorname{Smith}(2003$, p. 6) proposed that language teachers should engage in and reflect on the pedagogy for autonomy, which seems to be "particularly powerful means for developing teacher (-learner) autonomy". For teacher educators of teacher education programs, they should focus on developing (language teachers) a "willingness and capacity for self-directed teaching and teacher learning", linking into the pedagogy for leaner autonomy (Smith, 2003, p. 6).

In a pre-service teacher education context, Smith (2010) analyzed and evaluated the practical and ideological constraints on developing student "teacher-learner" autonomy. Smith (2010) concluded that one problem is the imprecision of the term "teacher autonomy" itself, another problem lies in the difficulty in the evaluation of the development of autonomy in learners. However, this research report sheds light on the empirical exploration of teacher-learner autonomy in the pre-service training programs.

Benson (2010) did a collective case study to find out secondary school teachers' experiences of constraints on teacher autonomy in English language teaching. The constraints from the research were "systemic", contextualized and primarily organized around "Schemes of Work". It is concluded that teacher education may "benefit from a greater sensitivity to the affordances in teachers' working conditions for teacher autonomy and experimentation" (Benson, 2010, p. 274).

In Asian contexts, Nakata (2011) explored Japanese high school EFL teachers' readiness of promoting learner autonomy, and concluded that though teachers displayed dimensions of autonomy in some ways, were not completely ready to promote learner autonomy. According to Nakata (2011), the development of learner autonomy and teacher autonomy, to some degree, is influenced by contextual factors. Nevertheless, the contextual factors remain relatively underexplored. This implies that more empirical studies should be carried out to explore the contextual factors. Nakata (2011) put forward three dimensions concerning teacher autonomy: "behavioral, situational and psychological", which adds to the understanding of the connotation of teacher autonomy.

Chen (2011) used questionnaire survey and in-depths interviews, conducted a research on the correlations between teacher autonomy and learner autonomy. The findings of the study have two points: teacher autonomy has an overall and positive impact on learner autonomy, and the affective communication between teachers and students has a great effect on learner autonomy (Chen, 2011). Similarly, Zhang (2014) also conducted a study using questionnaire survey and interviews, found there existed positive correlation between teacher autonomy and 
learner autonomy in college English teaching under the information and technology contexts.

To sum up, as Little (1995) proposed that teacher education students should experience autonomy within teacher education programs. Likewise, Jiménez-Raya \& Vieria (2015) also assert that teacher education should enhance autonmy development. In fact, Teachers' professional knowledge, skills and commitment to the idea of autonomy will be a crucial factor in the effectiveness in any approach and practice to fostering learner autonomy. Nevertheless, in a climate of apparently ever-increasing desire for the promotion of language learner autonomy at least as expressed within professional discourse - it is indeed remarkable, that there have previously been so few accounts of practice and research in the area of pre-service or in-service teacher education for learner autonomy.

\section{Conclusion}

From the above discussion, we can sum up the following points. Firstly, language teachers should change their roles to ones that support, facilitate and promote the development and fostering of learner autonomy. Just as many researchers and scholars (e.g. Aoki, 2000, 2002; Dickinson, 1992; Pang, 2003; Xu, 2007) point out that language teacher is a very important influencing factor in fostering learner autonomy. For language teachers, it is not only their ethical and career responsibility, obligation and commitment to foster and develop learners' language communicative competence, but also more importantly, to facilitate and promote language learners' autonomy in learning. As a result, language teachers should be clear about their roles, functions and influences in the development of learner autonomy, and change their traditional roles to fostering learner autonomy and catering to individual needs.

Secondly, language teacher education programs should help student teachers not only learn the knowledge of learner autonomy, but also raise their awareness of teacher autonomy. As illustrated above, one significant issue that needs to be addressed in the future research is initial teacher training. It is noted by many researchers and teachers that the way language teachers were taught, to a certain extent, would determine their own pedagogical approach in practice. Just as Smith (2004) argued that language teachers cannot be expected to foster and develop learner autonomy if they themselves do not know what it is to be an autonomous learner. On account of this, a series of teacher educaiton and training programs, courses and educational practicum should be designed to well facilitate the development and fostering of the student teacher autonomy. If student teachers have the knowledge, conception and clear understanding about learner autonomy and teacher autonomy, they can apply what have learned and experienced into their language teaching practice.

Finally, in the future, even though challenging, more empirical research needs to be carried out to explore the relationship, development model and mechanism between language learner autonomy and teacher autonomy.

\section{Acknowledgements}

This research is supported by "the Fundamental Research Funds for the Central Universities" (Grant No. 2020FR007).

\section{References}

Allford, D., \& Pachler, N. (2007). Language, autonomy and the new learning environments. Bern: Peter Lang.

Anderson, L. W. (1987). The decline of teacher autonomy: Tears or cheers? International Review of Education, 33, 357-373. https://doi.org/10.1007/BF00615308

Aoki, N. (2000). Affect and the role of teacher in the development of learner autonomy. In J. Arnold (Ed.), Affect in language learning (pp. 142-154). Beijing: Foreign Language Teaching and Research Press.

Aoki, N. (2002). Aspects of teacher autonomy: Capacity, freedom, and responsibility. In P. Benson, \& S. Toogood (Eds.), Learner autonomy 7: Challenges to research and practice (pp. 111-124). Dublin: Authentik.

Arnold, J. (Ed.). (2000). Affect in language learning. Beijing: Foreign Language Teaching and Research Press.

Benson, P. (1997). The philosophy and politics of learner autonomy. In P. Benson, \& P. Voller (Eds.), Autonomy and independence in language learning ( $\mathrm{pp}$. 18-34). London: Longman. https://doi.org/10.4324/9781315842172-3

Benson, P. (2004). Learner autonomy in the classroom. In D. Nunan (Ed.), Practical English language teaching (pp. 290-308). Beijing: Higher Education Press.

Benson, P. (2005). Teaching and researching autonomy in language learning. Beijing: Foreign Language Teaching and Research Press.

Benson, P. (2006). Autonomy in language teaching and learning. Language Teaching, 40, 21-40. 
https://doi.org/10.1017/S0261444806003958

Benson, P. (2010). Teacher education and teacher autonomy: Creating spaces for experimentation in secondary school English language teaching. Language Teaching Research, 14(3), 259-275. https://doi.org/10.1177/1362168810365236

Benson, P. (2011). Teaching and researching autonomy (2nd ed.). Harlow: Pearson Education Limited.

Benson, P., \& Voller, P. (Eds.). (1997). Autonomy and independence in language learning. London: Longman.

Breen, M. P., \& Mann, S. J. (1997).Shooting arrows at the sun: Perspectives on a pedagogy for autonomy. In P. Benson, \& P. Voller (Eds.), Autonomy and independence in language learning (pp. 132-149). London: Longman. https://doi.org/10.4324/9781315842172-11

Broady, E., \& Kenning, M. M. (Eds.). (1996). Promoting learner autonomy in university language teaching. London: Middlesex University Printing Services.

Chen, Y. (2011). A study on the correlations between teacher autonomy and learner autonomy. Technology Enhanced Foreign Language Education, 140(7), 55-60.

Cotterall, S. (1995). Readiness for autonomy: Investigating learner beliefs. System, 23(2), 195-205. https://doi.org/10.1016/0346-251X(95)00008-8

Dickinson, L. (1987). Self-instruction in language learning. Cambridge: Cambridge University Press.

Dickinson, L. (1992). Learner autonomy 2: Learning training for language learning. Dublin: Authentik.

Gardner, D., \& Miller, L. (2002). Establishing self-access: From theory to practice. Shanghai: Shanghai Foreign Language Education Press.

Gremmo, M-J., \& Riley, P. (1995). Autonomy, self-direction and self-access in language teaching and learning: The history of an idea. System, 23(2), 151-164. https://doi.org/10.1016/0346-251X(95)00002-2

Han, L. G. (2013). Research on university EFL teachers' pedagogical knowledge for the development of learner autonomy. Beijing: Modern Education Press.

Han, L. G. (2017). The connotations of language teacher autonomy. English Language Teaching, 10(10), 134-139.

Hedge, T. (2002). Teaching and learning in the language classroom. Shanghai: Shanghai Foreign Language Education Press.

Higgs, J. (1988). Planning learning experiences to promote autonomous learning. In D. Boud (Ed.), Developing student autonomy in learning (2nd ed., pp. 40-58). London: Kogan.

Higher Education Department of the Ministry of Education. (2007). College English curriculum requirements. Shanghai: Shanghai Foreign Language Education Press.

Ho, J., \& Crookall, D. (1995). Breaking with Chinese cultural traditions: Learner autonomy in English language teaching. System, 23(2), 235-243. https://doi.org/10.1016/0346-251X(95)00011-8

Holec, H. (1981). Autonomy and foreign language learning. Oxford: Pergamon Press.

Huang, J., \& Benson, P. (2007). Research on teacher autonomy in second language education. Foreign Languages and Their Teaching, 2, 33-37.

Hutchinson, T., \& Waters, A. (1987). English for specific purposes. Cambridge: Cambridge University Press. https://doi.org/10.1017/CBO9780511733031

Jiménez-Raya, M. (2008) Learner autonomy as an educational goal in modern languages education. In M. Jiménez-Raya, and T. Lamb (Eds.), Pedagogy for Autonomy in Modern Languages Education: Theory, Practice, and Teacher Education (pp. 3-15). Dublin: Authentik.

Jiménez-Raya, M. (2009). Teacher education for learner autonomy: An analysis of the EuroPAL contribution to a knowledge base. Innovation in Language learning and Teaching, 3(3), 221-238. https://doi.org/10.1080/17501220903404459

Jiménez-Raya, M., \& Flávia V. (2015). Enhancing autonomy in language education: A case-based approach to teacher and learner development. Berlin/Boston: Walter de Gruyter. https://doi.org/10.1515/9781614511359

Jiménez-Raya, M., \& Lamb, T. (Eds.). (2008). Pedagogy for autonomy in modern languages education: Theory, 
practice, and teacher education. Dublin: Authentik.

Knowles, M. (1975). Self-directed learning: A guide for learners and teachers. Chicago: Association Press.

Lamb, T., \& Reinders, H. (Eds.). (2008). Learner and teacher autonomy: Concepts, realities, and responses. Amsterdam/Philadelphia: Benjamins. https://doi.org/10.1075/aals.1

Little, D. (1991). Learner autonomy 1: Definitions, issues and problems. Dublin: Authentik.

Little, D. (1995). Learning as dialogue: The dependence of learner autonomy on teacher autonomy. System, 23(2), 175-181. https://doi.org/10.1016/0346-251X(95)00006-6

Little, D. (2004). Learner autonomy, teacher autonomy and the European Language portfolio. UNTELE, 1-3.

Little, D. (2007). Introduction: Reconstructing learner and teacher autonomy in language education. In A. Barfield, \& S. Brown (Eds.), Reconstructing autonomy in language education: Inquiry and innovation (pp. 1-12). New York: Palgrave Macmillan. https://doi.org/10.1057/9780230596443_1

Little, D. (2008). Knowledge about language and learner autonomy. In J. Cenoz, \& N. H. Hornberger (Eds.), Encyclopedia of language and education (2nd ed., Vol. 6, pp. 247-258). New York: Springer Science + Business Media, LLC.

Littlewood, W. (1999). Defining and developing autonomy in East Asian contexts. Applied Linguistics, 20(1), 71-94. https://doi.org/10.1093/applin/20.1.71

McGrath, I. (2000). Teacher autonomy. In B. Sinclair, I. McGrath, \& T. Lamb (Eds.), Learner autonomy, teacher autonomy: Future directions (pp. 100-110). Harlow: Longman.

Nakata, Y. (2011). Teachers' readiness for promoting learner autonomy: A study of Japanese EFL high school teachers. Teaching and Teacher Education, 27, 900-910. https://doi.org/10.1016/j.tate.2011.03.001

Nunan, D. (1993). From learning-centeredness to learner-centeredness. Applied Language Learning, 4, 1-18.

Pang, W. G. (2003). Self-regulated learning: Principles and educational applications. Shanghai: East China Normal University Press.

Shu, D. F., \& Zhuang, Z. X. (2008). Modern foreign language teaching: Theories, practice and approaches. Shanghai: Shanghai Foreign Language Education Press.

Sinclair, B., \& Lamb, T. (Eds.). (2000). Learner autonomy, teacher autonomy: Future directions. London: Longman.

Smith, R. C. (2003). Teacher education for teacher-learner autonomy. In J. Gollin, G. Ferguson, \& H. Trappes-Lomax (Eds.), Symposium for language teacher educators: Papers from three IALS Symposia. Edinburgh: University of Edinburgh. https://doi.org/10.1016/S0742-051X(03)00016-7

Smith, R. C. (2008). Learner autonomy. ELT Journal, 62(4), 395-397. https://doi.org/10.1093/elt/ccn038

Smith, R. C. (2010). Developing teacher-learner autonomy: Constraints and opportunities in pre-service training.

Smith, R., \& Vieira, F. (2009). Teacher education for learner autonomy: Building a knowledge base. Innovation in Language learning and Teaching, 3(3), 215-220. https://doi.org/10.1080/17501220903404434

Thavenius, C. (1999). Teacher autonomy for learner autonomy. In S. Cotterall, \& D. Crabbe (Eds.), Learner autonomy in language learning: Defining the field and effecting change (pp. 159-163). Frankfurt am Main: Peter Lang.

Ushioda, E. (1996). Learner autonomy 5: The role of motivation. Dublin: Authentik.

Vieira, F. (2008). Introduction to section III: Teacher education for teacher and learner autonomy. In M. Jiménez-Raya, \& T. Lamb (Eds.), Pedagogy for autonomy in modern languages education: Theory, practice, and teacher education (pp. 199-201). Dublin: Authentik.

Voller, P. (1997). Does the teacher have a role in autonomous language learning? In P. Benson, \& P. Voller (Eds.), Autonomy and independence in language learning ( $\mathrm{pp}$. 98-113). London: Longman. https://doi.org/10.4324/9781315842172-9

Wenden, A. L. (1991). Learner strategies for learner autonomy. London: Prentice Hall.

$\mathrm{Xu}, \mathrm{H}$. (2015). The development of teacher autonomy in collaborative lesson preparation: A multiple-case study of EFL teachers in China. System, 52, 139-148. https://doi.org/10.1016/j.system.2015.05.007 
$\mathrm{Xu}$, J. F. (2007). The theory and practice of university foreign language autonomous learning. Beijing: China Social Sciences Publishing House.

$\mathrm{Xu}, \mathrm{J}$. F., \& Xu. L. (2004). Exploring College English teachers' roles in the autonomous learning mode. Higher Education Research, 3, 77-79.

Yang, N. (1998). Exploring a new role for teachers: Promoting learner autonomy. System, 26, 127-135. https://doi.org/10.1016/S0346-251X(97)00069-9

Zhang, M. L. (2014). A study on the correlation on teacher autonomy and learner autonomy under the information and technology contexts. Journal of Wuhan Metallurgical Manager's Institute, 24(2), 58-60.

\section{Copyrights}

Copyright for this article is retained by the author(s), with first publication rights granted to the journal.

This is an open-access article distributed under the terms and conditions of the Creative Commons Attribution license (http://creativecommons.org/licenses/by/4.0/). 